\title{
Clerodendron glandulosum Coleb., Verbenaceae, ameliorates high fat diet-induced alteration in lipid and cholesterol metabolism in rats
}

\author{
Jadeja RN, Thounaojam MC, Ansarullah, Devkar RV, Ramachandran AV \\ Division of Phytotherapeutics and Metabolic Endocrinology, Department of Zoology, Faculty of Science, \\ The M. S. University of Baroda, 390002 Vadodara-Gujarat, India.
}

\begin{abstract}
RESUMO: "Clerodendron glandulosum Coleb., Verbenaceae, melhora a dieta rica em gordura induzida por alteração no metabolismo de lipídios e colesterol em ratos." Este estudo foi realizado para avaliar a eficácia do extrato liofilizado das folhas de Clerodendron glandulosum Coleb., Verbenaceae (FECG), em alterar o metabolismo de lipídios e colesterol em ratos hiperlipidêmicos alimentados em uma dieta rica em gordura. Plasma e perfil lipídico hepático, lipídeos e enzimas que metabolizam o colesterol em tecidos-alvo e o conteúdo de lipídeos fecais totais e ácidos biliares foram avaliados em ratos normolipidêmicos e hiperlipidêmicos tratados com FECG. Os resultados foram comparados com a droga sintética hipolipemiante Lovastatina (LVS). Os resultados indicam que FECG foi capaz de regular positivamente a hiperlipidemia induzida experimentalmente por alteração significativa no perfil lipídico do plasma e tecidos. Estes resultados podem ser atribuídos à absorção reduzida, a eliminação efetiva e catabolismo aumentado de lipídeos e colesterol, possivelmente devido ao alto teor de saponina e fitoesteróis em C. glandulosum Coleb. Uso de extrato de C. glandulosum como um possível agente terapêutico contra a hipercolesterolemia e hipertrigliceridemia é indicado.
\end{abstract}

Unitermos: Clerodendron glandulosum, Verbenaceae, hiperlipidemia, hipercolesterolemia.

\begin{abstract}
The present study was undertaken to evaluate the efficacy of freeze dried extract of Clerodendron glandulosum Coleb., Verbenaceae, leaves (FECG) on alteration in lipid and cholesterol metabolism in high fat diet fed hyperlipidemic rats. Plasma and hepatic lipid profiles, lipid and cholesterol metabolizing enzymes in target tissues and fecal total lipids and bile acid contents were evaluated in FECG treated normolipidemic and hyperlipidemic rats. These results were compared with synthetic hypolipidemic drug Lovastatin (LVS). Results indicate that FECG was able to positively regulate induced experimental hyperlipidemia by significant alteration in plasma and tissue lipid profiles. These results can be attributed to reduced absorption, effective elimination and augmented catabolism of lipids and cholesterol possibly due to high content of saponin and phytosterols in C. glandulosum. Use of C. glandulosum extract as a potential therapeutic agent against hypercholesterolemia and hypertriglyceridemia is indicated.
\end{abstract}

Keywords: Clerodendron glandulosum, Verbenaceae, hyperlipidemia, hypercholesterolemia.

\section{INTRODUCTION}

Diets containing high amount of fats or cholesterol lead to both hypercholesterolemia and hypertriglycedemia which are major prognosis for cardiovascular diseases (Reiner \& Tedeschi-Reiner, 2006); and leading causes of death in developing and developed countries (Yokozawa et al., 2003) The World Health Organization (WHO) estimates that sixty per cent of the world's cardiac patients will be Indians by 2010 (Radhakrisnan, 2008). In view of the adverse effects of synthetic lipid-lowering drugs, the search for natural products with lipid-lowering potential and with minimal or no side effect is recommended (Adaramoye et al., 2008). In recent times research interest has focused on various herbs that possess hypolipidemic property that may be useful in reducing the risk of cardiovascular disease (Craig, 1999). Because of their perceived effectiveness, minimal side effects and, relative low cost, herbal drugs are prescribed widely even when their biologically active compounds are unknown (Valiathian, 1998). North eastern states of India (biodiversity hotspots) house a treasuretrove of plants with novel medicinal properties (Albert $\&$ Kuldip, 2006). These plants have found a prime place in the indigenous system of medicine and are in focus for evaluation of their beneficial effects (Sudhir, 2002). Clerodendron glandulosum Coleb., Verbenaceae, is a herb 
found in many part of north east India and used by rural and urban people against diabetes obesity and hypertension. Apatani Tribe uses the leaves of $C$. glandulosum for controlling hypertension and fever (Kala, 2005), while the tender shoots are used by people of Debaru biosphere region against abdominal pain (Puryakashtha et al., 2005). Previous study from our laboratory had documented antioxidant property of $C$. glandulosum extract (Jadeja et al., 2009).This inventory is an effort to evaluate efficacy of C. glandulosum extract on alterations in lipid and cholesterol metabolism in hyperlipidemic rats.

\section{MATERIAL AND METHODS}

\section{Plant material}

Clerodendron glandulosum Coleb., Verbenaceae, leaves were collected from Imphal district India in the month of June and shade dried. The plant was identified by Dr. Hemchand Singh, at the Department of Botany, D.M. College of Science Manipur, Imphal and a sample (voucher specimen No.405) was deposited at the herbarium of the Department of Botany.

\section{Preparation of freeze dried extract}

Leaves of $C$. glandulosum were shade dried and fine powdered. Powdered leaves (100 g) was boiled in distilled water at $100{ }^{\circ} \mathrm{C}$ for $3 \mathrm{~h}$. Resulting filtrate was concentrated by heating to obtain a semisolid paste that was later freeze dried resulting in a total yield of $28 \%$ w/w. Different doses of freeze dried extract (FECG) were prepared by dissolving a known weight of dried paste in $0.5 \%$ carboxy methylcellulose (CMC).

\section{Phytochemical analysis}

The quantitative phytochemical analysis of C. glandulosum leaves for saponins (Xi et al., 2007), phytosterols (Goad \& Akihisa, 1997), ascorbic acid (Barakat et al., 1973), polyphenols (Yen \& Hsieh, 1998) and flavanoids (Chang et al., 2002) was carried out.

\section{Experimental animals}

Female Charles foster albino rats (180-220 g) were housed and maintained in clean polypropylene cages under controlled room temperature $\left(24 \pm 2^{\circ} \mathrm{C}\right)$ and were fed with commercially available rat chow (SLD; M/s Pranav Agro Ltd., Baroda) or hyperlipidemic diet (HFD; Rathi et al., 1984) and provided with water ad libitum. Experiments on animals were performed in accordance with guidelines of the Institutional Animal Ethical Committee (Approval No.827/ac/04/CPCSEA).

\section{Experimental design}

Fifty four animals were divided into nine groups ( $n=6$ per group). Groups I and V were fed with SLD and HFD respectively. Groups II, III, and IV were maintained on SLD and orally administered with 200, 400 or $800 \mathrm{mg} /$ $\mathrm{kg}$ FECG extract daily. Groups VI, VII and VIII were maintained on HFD and administered with FECG extract as mentioned above. Group IX was fed with HFD and received synthetic hypolipidemic agent, lovastatin (LVS; 5 $\mathrm{mg} / \mathrm{kg} \mathrm{BW}$ ). Animals were maintained for a total of 42 days (six weeks) during which they were orally administered with vehicle, extract or LVS by gastric intubation.

\section{Lipid profile}

Plasma Total Cholesterol (TC), Triglyceride (TG) and High Density Lipoprotein (HDL) were analyzed using commercially available kits (Merck diagnostics Ltd, Mumbai, India). Very Low Density Lipoproteins (VLDL) and Low Density Lipoprotein (LDL) were calculated by Friedwald's formula (Friedewald et al., 1972). Hepatic and fecal lipids were extracted in chloroform:methanol (2:1) mixture and dried. Total Lipids (TL) were estimated by gravimetric analysis (Folch et al., 1957). Dried lipid extract was dissolved in 1\% triton X 100 (Thounaojam et al., 2009) and TC and TG were analyzed using above mentioned kits.

\section{Fecal cholic acid (CA) and deoxycholic acid (DCA)}

Fecal samples from each experiment group were collected on every third day between days thirty one and forty two of study. Fecal samples were dried, eluted with absolute alcohol, filtered and processed for estimation of CA and DCA (Mosback et al., 1954).

\section{Estimation of lipid metabolizing enzymes}

Freshly excised tissues (liver and adipose tissues) were rinsed with $0.5 \mathrm{M} \mathrm{KCl}$ and kept in $-80{ }^{\circ} \mathrm{C}$ for further use. Activity levels of Lipoprotein lipase (LPL; EC 3.1.1.34) were estimated in fresh tissue homogenates (Mays \& Felts, 1968; Itaya \& Ui, 1965). Heparin (50 units/ rats) was injected intravenously to facilitate release of endothelium bound LPL, two min before blood collection. Plasma was separated and post-heparin lypolytic activity (PHLA) was assayed (Qi et al., 2006).

\section{Estimation of cholesterol metabolizing enzymes}

Activity levels of Lecithin-Cholesterol Acyltransferase (LCAT, EC 2.3.1.43) was assayed in plasma by the method of Legraud et al. (1979) with modifications by Hitz et al.(1983) HMG CoA reductase (HMG-CoA reductase, EC 1.1.1.34) activity was assayed as per the method of Rao \& Ramakrishnan (1975) 
and expressed as inversely proportional to the mevalonate content. Cholesterol ester synthase (CES, EC 2.3.1.26) was assayed by the method of Kothari et al. (1973) in liver and intestine. Protein content in liver, adipose tissue and intestine was analyzed by the method of Lowry et al. (1951).

\section{Acute oral toxicity in mice}

$\mathrm{Balb} / \mathrm{c}$ mice of either sex were divided into groups of six mice each (three male \& three female). They were orally administered with a single dose of FECG at $1.6 \mathrm{~g}$, $3.2 \mathrm{~g}, 6.4 \mathrm{~g}$ and $8.0 \mathrm{~g} / \mathrm{kg}$ bodyweight. They were observed for $48 \mathrm{~h}$ post administration.

\section{Statistical analysis}

Statistical evaluation of the data was done by one way ANOVA followed by Bonferroni's multiple comparison test .The results are expressed as mean \pm S.E.M using Graph Pad Prism version 3.0 for Windows, Graph Pad Software, San Diego California USA.

\section{RESULTS}

\section{Phytochemical analysis and acute oral toxicity}

Quantitative phytochemical analysis of $C$. glandulosum leaf extract recorded $4.36 \%$ flavanoids, $6.39 \%$ sterols, 5.23\% saponins, 3.22\% polyphenols and 5.96\% vitamin $\mathrm{C}$. There was no mortality and gross behavioral changes in acute oral toxicity test. Plasma analysis for liver and kidney functions did not record any adverse effect in FECG administered rats (Data not shown).

\section{Plasma and hepatic lipid profile}

FECG did not record any significant effect in SLD fed rats but, the extract had a dose dependent effect in reversing the altered serum and hepatic lipid profile induced by HFD (Table 1 and 2). A comparison of FECG treated groups with LVS treated rats revealed a better response in the former with respect to plasma triglyceride and HDL levels (Table 1).

\section{Fecal lipid profile and bile acid content}

HFD rats did not show any significant changes in fecal TL, TC, TG, cholic acid and deoxycholic acid contents (Table 3 ). The extract fed rats recorded a highly significant increment in fecal TL, TC and TG contents with all the three doses compared to HFD rats $(p<0.001)$. HFD+FECG recorded a dose dependent increment in fecal CA and DCA compared to HFD groups ( $p<0.001)$. HFD+LVS rats recorded highly significant increment in fecal TL and TC $(p<0.001)$ and a non significant increment in fecal TG, CA and DCA.

\section{Lipid metabolizing enzymes}

HFD rats recorded significant decrement in activity levels of PHLA, and LPL in adipose tissue and liver $(p<0.001)$. HFD+FECG $200 \mathrm{mg} / \mathrm{kg}$ did not record any significant effect in PHLA and LPL activities. HFD+FESR (400 and $800 \mathrm{mg} / \mathrm{kg}$ ) significant resistance towards decrease in PHLA and LPL activities compared to HFD rats $(p<0.001)$. HFD+LVS rats registered non significant effect in PHLA and LPL activities compared to HFD group (Table 4). The extract had no significant effect in control rats fed with SLD (Table 4).

\section{Cholesterol metabolizing enzymes}

HFD rats recorded a significant decrement in plasma LCAT activity $(p<0.001)$ and increment in hepatic and intestinal CES $(p<0.001)$. Hepatic HMG Co A reductase activity registered a non significant alteration in HFD rats. Higher doses of FESR (400 and $800 \mathrm{mg} / \mathrm{kg}$ ) depicted dose dependent decrement in the activity level of HMG Co A reductase $(p<0.05$ and $p<0.01)$ and prevented decrease in plasma LCAT activity $(p<0.001)$. HFD+FECG rats recorded a dose dependent protective effect against decrement in hepatic and intestinal CES activity (Table $6)$. HFD+LVS rats recorded significant decrease in $\mathrm{HMG}$ Co A reductase activity $(p<0.001)$ along with protective effect against the decrease in intestinal and hepatic CES activities $(p<0.01)$ and a non significant change in plasma LCAT activity compared to HFD rats. The extract had no significant effect in hepatic HMG Co A reductase, plasma LCAT and, CES activities in liver and intestine in SLD fed rats (Table 5).

\section{DISCUSSION}

The present study has investigated the effects of FECG on lipid and cholesterol metabolisms in normolipidemic and hyperlipidemic rats. The cholesterol lowering property of FECG could be due to increased excretion of cholesterol and bile acids (Cholic acid \& Deoxycholic acid) in feaces. These observed effects can be attributed to presence of phytosterol in FECG as; phytosterols possesses greater affinity for micelles than cholesterol and reduce incorporation of cholesterol in micelles (Ikeda \& Sugano, 1998). Liver serves as the primary site for elimination of cholesterol from the body. In the liver, free cholesterol is either secreted directly into bile or it can be converted to oxysterols (Zhang et al., 2001). Oxysterols stimulate expression of CYP7A1, thereby increasing conversion of cholesterol to bile acids (Lehmann et al., 1997). High content of fecal bile acids in HFD+FECG rats (CA \& DCA) indicates that FECG stimulates removal of excess cholesterol via increased bile 
acid excretion in feaces.

Observed decrease in HMG Co A reductase activity in HFD+FECG rats, indicates diminished de novo cholesterol synthesis. Decreased hepatic cholesterol levels are known to induce LDL receptor expression to promote LDL clearance from circulation in order to maintain hepatic cholesterol homeostasis (Ma et al., 1986). Thus it can be speculated that FECG decreases circulating LDL via increased LDL-R expression. A decreased plasma LDL level recorded in HFD+FECG groups corroborates this hypothesis.

Cholesterol ester synthase (CES) in known to be involved in esterification and incorporation of free cholesterol in chylomicron and VLDL (Klein \& Rudel, 1983; Rudel \& Shelness , 2000). Recorded low activity of CES in intestine and liver of HFD+FECG rats indicates decreased esterification of cholesterol resulting in impaired incorporation of Cholestryl ester into chylomicrons and VLDL leading to, low levels of circulating cholesterol (Table 2) along with high fecal cholesterol content (Table 4). These observed effects are in accordance with other published reports on the effect of plant products on CES activity (Song et al., 2002).

A low level of HDL is directly correlated with an increased risk of cardiovascular disease (Wilson et al., 1988). FECG recorded a dose dependent increment in plasma HDL levels in HFD fed rats (Table 2) that can be correlated with an increased plasma LCAT activity (Table 6). Flavanoids and polyphenols are known to increase HDL levels (Daniel et al., 2003). Presence of flavanoids in FECG $(4.36 \%)$ could thus be responsible for the observed higher HDL levels.
Phytocompounds like saponins are known to inhibit pancreatic lipase in HFD fed animals, leading to greater fat excretion due to reduced intestinal absorption of dietary fats (Han et al., 2002). Hence, increased elimination of TG through feaces of HFD+FECG rats seen in the present study can be related with the high saponin content $(4.5 \%)$ in FECG. LPL hydrolyses triacylglycerols (TG) from chylomicrons thereby generating nonesterified fatty acids (NEFA) for subsequent tissue uptake and metabolism (Sattler et al., 1996) HFD rats in the present study recorded suppressed post heparin lypolytic activity levels (PHLA) while HFD+FECG rats recorded significantly elevated levels. These observations are in accordance with the previous studies in hyperlipidemic rats fed with plant products (Khanna et al., 1996) .Similarly, lipoprotein lipase (LPL) is related to hydrolysis of TG molecules and lypolytic activity in tissues. Elevated LPL activity in hepatic and adipose tissues of HFD+FESR rats could be held responsible for reducing tissue lipid load.

In recent times, therapeutic approach for treatment of hyperlipidemia has been shifted towards a combination therapy with synthetic drugs (i.e. niacin extended lovastatin release tablet) as, cholesterol lowering drugs are having a moderate effect on triacylglyceride levels (Richard, 2008). Another drawback of synthetic drugs is their inability to increase HDL levels (Wilson, 1990). Present study clearly indicates that treatment with Clerodendron glandulosum Coleb. (Verbenaceae) is able to significantly lower plasma TG levels and elevates plasma HDL levels, and can therefore be a candidate for alternative therapy for treatment of hypercholesterolemia and hypertriglyceridemia.

Table 1. Effect of FECG and LVS on plasma lipid profile.

\begin{tabular}{ccccccc}
\hline Groups & Treatment & $\begin{array}{c}\text { Total } \\
\text { cholesterol }\end{array}$ & Triglycerides $^{\mathrm{s}}$ & HDL $^{\mathrm{s}}$ & LDL $^{\mathrm{s}}$ & VLDL $^{\mathrm{s}}$ \\
\hline I & SLD & $32.80 \pm 3.57$ & $40.86 \pm 5.31$ & $20.70 \pm 1.71$ & $20.27 \pm 3.00$ & $8.17 \pm 0.86$ \\
II & SLD+200mgCG & $33.91 \pm 8.34$ & $39.63 \pm 2.45$ & $19.24 \pm 1.51$ & $22.59 \pm 2.49$ & $7.92 \pm 0.49$ \\
III & SLD+400mgCG & $28.57 \pm 2.87$ & $44.26 \pm 2.01$ & $19.48 \pm 2.31$ & $18.43 \pm 2.03$ & $8.85 \pm 0.40$ \\
IV & SLD+800mgCG & $30.99 \pm 5.53$ & $44.48 \pm 3.00$ & $17.67 \pm 1.51$ & $22.22 \pm 6.01$ & $8.89 \pm 0.59$ \\
V & HFD & $93.36 \pm 5.36^{\mathrm{c}}$ & $170.29 \pm 10.99^{\mathrm{c}}$ & $9.20 \pm 1.21 \mathrm{C}$ & $118.21 \pm 5.06^{\mathrm{c}}$ & $34.05 \pm 1.02^{\mathrm{c}}$ \\
VI & HFD+200mgCG & $54.84 \pm 5.96^{\mathrm{b}}$ & $80.69 \pm 6.69^{\mathrm{b}}$ & $16.49 \pm 1.00^{\mathrm{a}}$ & $47.50 \pm 3.07^{\mathrm{c}}$ & $16.13 \pm 0.34^{\mathrm{b}}$ \\
VII & HFD+400mgCG & $42.36 \pm 3.69^{\mathrm{c}}$ & $56.17 \pm 9.67^{\mathrm{c}}$ & $22.31 \pm 1.21^{\mathrm{b}}$ & $31.28 \pm 2.36^{\mathrm{c}}$ & $11.23 \pm 0.56^{\mathrm{c}}$ \\
VIII & HFD+800mgCG & $32.03 \pm 3.79^{\mathrm{c}}$ & $48.05 \pm 5.69^{\mathrm{c}}$ & $32.51 \pm 3.95^{\mathrm{c}}$ & $20.15 \pm 2.67^{\mathrm{c}}$ & $9.61 \pm 0.93^{\mathrm{c}}$ \\
IX & HFD+5mgLVS & $36.43 \pm 4.60^{\mathrm{c}}$ & $72.05 \pm 5.65^{\mathrm{b}}$ & $18.68 \pm 1.68^{\mathrm{a}}$ & $28.16 \pm 3.96^{\mathrm{c}}$ & $14.41 \pm 1.13^{\mathrm{b}}$ \\
\hline
\end{tabular}

Where $\$=\mathrm{mg} / \mathrm{dL} ; \mathrm{CG}=$ C. glandulosum; $\mathrm{a}=p<0.05, \mathrm{~b}=p<0.01, \mathrm{c}=p<0.001$ and $\mathrm{ns}=$ non significant when, Group V vs. Group VI, VII, VIII and IX. A $=p<0.05, \mathrm{~B}=p<0.01, \mathrm{C}=p<0.001$ and NS = non significant when, Group I vs. Group V. 
Table 2. Effect of FECG and LVS on liver lipid profile.

\begin{tabular}{ccccc}
\hline Groups & Treatment & Total lipids $^{\#}$ & Cholesterol $^{\#}$ & Triglycerides $^{\#}$ \\
\hline I & SLD & $61.30 \pm 1.30$ & $9.04 \pm 0.49$ & $19.50 \pm 1.11$ \\
II & SLD+200mgCG & $61.70 \pm 1.41$ & $9.90 \pm 0.76$ & $19.70 \pm 1.19$ \\
III & SLD+400mgCG & $63.10 \pm 1.39$ & $9.96 \pm 1.08$ & $20.60 \pm 1.72$ \\
IV & SLD+800mgCG & $62.00 \pm 1.94$ & $11.80 \pm 0.59$ & $18.90 \pm 0.545$ \\
V & HFD & $127.20 \pm 5.21^{\mathrm{c}}$ & $22.80 \pm 1.49^{\mathrm{c}}$ & $51.50 \pm 1.67 \mathrm{C}$ \\
VI & HFD+200mgCG & $96.70 \pm 5.78^{\mathrm{c}}$ & $14.80 \pm 0.96^{\mathrm{b}}$ & $38.80 \pm 0.94^{\mathrm{c}}$ \\
VII & HFD+400mgCG & $89.30 \pm 2.81^{\mathrm{c}}$ & $13.70 \pm 1.67^{\mathrm{c}}$ & $32.80 \pm 2.60^{\mathrm{c}}$ \\
VIII & HFD+800mgCG & $69.30 \pm 1.54^{\mathrm{c}}$ & $10.90 \pm 1.63^{\mathrm{c}}$ & $23.70 \pm 1.45^{\mathrm{c}}$ \\
IX & HFD+5mgLVS & $74.80 \pm 2.53^{\mathrm{c}}$ & $12.60 \pm 0.20^{\mathrm{c}}$ & $41.70 \pm 1.07^{\mathrm{b}}$ \\
\hline
\end{tabular}

$\#=\mathrm{mg} / \mathrm{g} ; \mathrm{CG}=$ C. glandulosum $; \mathrm{a}=\mathrm{p}<0.05, \mathrm{~b}=\mathrm{p}<0.01, \mathrm{c}=\mathrm{p}<0.001$ and $\mathrm{ns}=$ non significant when, Group V vs. Group VI, VII, VIII and IX. A $=p<0.05, \mathrm{~B}=\mathrm{p}<0.01, \mathrm{C}=\mathrm{p}<0.001$ and NS $=$ non significant when, Group I vs. Group V.

Table 3. Effect of FECG and LVS on fecal lipids and bile acid content.

\begin{tabular}{ccccccc}
\hline Groups & Treatment & Total lipids $^{\$}$ & Cholesterol $^{\$}$ & Triglycerides $^{\$}$ & Cholic acid $^{\#}$ & Deoxycholic acid $^{\#}$ \\
\hline I & SLD & $28.30 \pm 2.07$ & $8.43 \pm 0.45$ & $8.82 \pm 0.49$ & $29.90 \pm 1.23$ & $20.60 \pm 1.67$ \\
II & SLD+200mgCG & $29.30 \pm 2.16$ & $6.42 \pm 0.27$ & $8.52 \pm 0.31$ & $31.00 \pm 1.43$ & $22.00 \pm 1.55$ \\
III & SLD+400mgCG & $32.00 \pm 1.55$ & $5.00 \pm 0.54$ & $9.13 \pm 0.15$ & $31.70 \pm 1.80$ & $23.40 \pm 2.46$ \\
IV & SLD+800mgCG & $31.20 \pm 2.20$ & $4.04 \pm 0.28$ & $10.30 \pm 0.34$ & $32.00 \pm 2.31$ & $21.80 \pm 1.71$ \\
V & HFD & $30.00 \pm 1.42^{\mathrm{NS}}$ & $6.93 \pm 1.39^{\mathrm{NS}}$ & $11.30 \pm 0.57^{\mathrm{NS}}$ & $35.50 \pm 3.07^{\mathrm{NS}}$ & $24.40 \pm 2.30^{\mathrm{NS}}$ \\
VI & HFD+200mgCG & $50.20 \pm 1.78^{\mathrm{c}}$ & $19.08 \pm 1.52^{\mathrm{c}}$ & $21.90 \pm 1.23^{\mathrm{c}}$ & $58.90 \pm 4.17^{\mathrm{b}}$ & $36.10 \pm 2.29^{\mathrm{a}}$ \\
VII & HFD+400mgCG & $66.70 \pm 2.15^{\mathrm{c}}$ & $24.15 \pm 0.03^{\mathrm{c}}$ & $25.40 \pm 1.35^{\mathrm{c}}$ & $25.40 \pm 1.35^{\mathrm{c}}$ & $69.00 \pm 2.52^{\mathrm{c}}$ \\
VIII & HFD+800mgCG & $77.60 \pm 1.48^{\mathrm{c}}$ & $27.66 \pm 0.66^{\mathrm{c}}$ & $29.00 \pm 0.87 \mathrm{c}$ & $77.60 \pm 7.50^{\mathrm{c}}$ & $53.90 \pm 3.81^{\mathrm{c}}$ \\
IX & HFD+5mgLVS & $41.10 \pm 3.43^{\mathrm{a}}$ & $14.25 \pm 1.90^{\mathrm{a}}$ & $15.80 \pm 2.29^{\mathrm{ns}}$ & $15.80 \pm 2.29^{\mathrm{ns}}$ & $33.80 \pm 1.74^{\mathrm{ns}}$ \\
\hline
\end{tabular}

Where $\$=\mathrm{mg} / \mathrm{g}$ feaces, $\#=\mu \mathrm{g} / \mathrm{g}$ feaces; $\mathrm{CG}=C$. glandulosum; $\mathrm{a}=\mathrm{p}<0.05, \mathrm{~b}=\mathrm{p}<0.01, \mathrm{c}=\mathrm{p}<0.001$ and $\mathrm{ns}=$ non significant when, Group V vs. Group VI, VII, VIII and IX. A $=p<0.05, B=p<0.01, C=p<0.001$ and NS = non significant when, Group I vs. Group V

Table 4. Effect of FECG and LVS on enzymes of lipid metabolism.

\begin{tabular}{|c|c|c|c|c|}
\hline Groups & Treatment & Post heparin lipolytic activity & $\begin{array}{c}\text { Lipoprotein } \\
\text { lipase }^{\$} \text { (Liver) }\end{array}$ & $\begin{array}{l}\text { Lipoprotein lipase } \\
\text { (Adipose) }\end{array}$ \\
\hline I & SLD & $14.41 \pm 0.42$ & $130.20 \pm 2.18$ & $68.93 \pm 1.46$ \\
\hline II & $\mathrm{SLD}+200 \mathrm{mgCG}$ & $14.00 \pm 0.40$ & $131.70 \pm 2.49$ & $73.73 \pm 2.17$ \\
\hline III & $\mathrm{SLD}+400 \mathrm{mgCG}$ & $14.00 \pm 0.44$ & $133.10 \pm 2.19$ & $77.01 \pm 1.76$ \\
\hline IV & SLD+800mgCG & $13.20 \pm 0.44$ & $132.00 \pm 2.29$ & $76.77 \pm 3.21$ \\
\hline $\mathrm{V}$ & HFD & $8.36 \pm 0.34^{\mathrm{C}}$ & $82.74 \pm 2.23^{\mathrm{C}}$ & $40.23 \pm 3.02^{\mathrm{C}}$ \\
\hline VI & $\mathrm{HFD}+200 \mathrm{mgCG}$ & $9.28 \pm 0.36^{\mathrm{NS}}$ & $86.76 \pm 3.49^{\mathrm{ns}}$ & $50.20 \pm 2.48^{\mathrm{ns}}$ \\
\hline VII & $\mathrm{HFD}+400 \mathrm{mgCG}$ & $12.60 \pm 0.59^{\mathrm{c}}$ & $106.30 \pm 2.06^{\mathrm{c}}$ & $64.50 \pm 2.91^{\mathrm{c}}$ \\
\hline VIII & $\mathrm{HFD}+800 \mathrm{mgCG}$ & $14.50 \pm 0.54^{\mathrm{c}}$ & $110.50 \pm 2.54^{\mathrm{c}}$ & $71.27 \pm 1.15^{\mathrm{c}}$ \\
\hline
\end{tabular}

$\$=\mu \mathrm{mol}$ of FFA formed $/ \mathrm{hr} / \mathrm{dl}$ plasma; $\mathrm{CG}=$ C. glandulosum; $\mathrm{a}=\mathrm{p}<0.05, \mathrm{~b}=\mathrm{p}<0.01, \mathrm{c}=\mathrm{p}<0.001$ and $\mathrm{ns}=$ non significant when, Group V vs. Group VI, VII, VIII and IX. A $=p<0.05, B=p<0.01, C=p<0.001$ and NS $=$ non significant when, Group I vs. Group V. 
Table 5. Effect of FECG and LVS on enzymes of cholesterol metabolism.

\begin{tabular}{cccccc}
\hline Groups & Treatment & $\begin{array}{c}\text { Hepatic HMG CoA } \\
\text { reductase activity }\end{array}$ & $\begin{array}{c}\text { Plasma lecithin } \\
\text { cholesterol acyl } \\
\text { transferase }^{\sharp}\end{array}$ & $\begin{array}{c}\text { Hepatic cholesterol } \\
\text { ester synthase }^{\circledR}\end{array}$ & $\begin{array}{c}\text { Intestine cholesterol } \\
\text { ester synthase }^{\circledR}\end{array}$ \\
\hline I & SLD & $2.22 \pm 0.11$ & $60.80 \pm 1.14$ & $11.20 \pm .41$ & $12.80 \pm 0.84$ \\
II & SLD+200mgCG & $2.49 \pm 0.19$ & $60.80 \pm 2.08$ & $9.86 \pm 0.79$ & $14.70 \pm 1.72$ \\
III & SLD+400mgCG & $2.16 \pm 0.23$ & $59.00 \pm 1.62$ & $10.40 \pm 0.56$ & $14.00 \pm 0.70$ \\
IV & SLD+800mgCG & $2.42 \pm 0.15$ & $60.50 \pm 1.30$ & $9.50 \pm 0.70$ & $12.90 \pm 0.45$ \\
V & HFD & $2.61 \pm 0.35^{\mathrm{NS}}$ & $32.30 \pm 1.09^{\mathrm{C}}$ & $29.60 \pm 2.05^{\mathrm{c}}$ & $35.00 \pm 2.08^{\mathrm{C}}$ \\
VI & HFD+200mgCG & $3.90 \pm 0.48^{\mathrm{ns}}$ & $38.50 \pm 1.26^{\mathrm{ns}}$ & $15.40 \pm 1.19^{\mathrm{c}}$ & $24.10 \pm 1.91^{\mathrm{b}}$ \\
VII & HFD+400mgCG & $4.47 \pm 0.17^{\mathrm{a}}$ & $43.50 \pm 1.77^{\mathrm{c}}$ & $12.20 \pm 0.56^{\mathrm{c}}$ & $24.00 \pm 0.75^{\mathrm{b}}$ \\
VIII & HFD+800mgCG & $4.92 \pm 0.15^{\mathrm{b}}$ & $49.40 \pm 1.89^{\mathrm{c}}$ & $10.20 \pm 1.37^{\mathrm{c}}$ & $21.00 \pm 1.40^{\mathrm{c}}$ \\
\hline
\end{tabular}

$\$=$ HMG CoA /mevalonate ratio. $\mathrm{CG}=$ C. glandulosum; $\#=$ nmol of cholesterol esterified $/ \mathrm{hr} / 1$ plasma. @ = $\mu$ mol of cholesterol esterified/hr/mg protein. $\mathrm{a}=\mathrm{p}<0.05, \mathrm{~b}=\mathrm{p}<0.01, \mathrm{c}=\mathrm{p}<0.001$ and ns $=$ non significant when, Group V vs. Group VI, VII, VIII and IX. $\mathrm{A}=\mathrm{p}<0.05, \mathrm{~B}=\mathrm{p}<0.01, \mathrm{C}=\mathrm{p}<0.001$ and $\mathrm{NS}=$ non significant when, Group I vs. Group V.

\section{ACKNOWLEDGEMENT}

The authors are grateful to University grants Commission, New Delhi for providing Financial Assistance in the form of JRFSMS scholarship.

\section{REFERENCES}

Adaramoye O A, Akintayo O, Achem J, Fafunso M A 2008. Lipid-lowering effects of methanolic extract of Vernonia amygdalina leaves in rats fed on high cholesterol diet. Vasc Health Risk Manag 4: 235-241.

Albert LS, Kuldip G 2006. Traditional use of medicinal plants by the Jaintia tribes in North Cachar Hills district of Assam, northeast India. J Ethnobiol Ethnomed 2: 33.

Barakat MZ, Shehab SK, Darwish N, Zahermy EI 1973. Determination of ascorbic acid from plants. Anal biochem 53: 225-247.

Chang C, Yang M, Wen H, Chern J 2002. Estimation of total flavonoid content in propolis by two complementary colorimetric methods. J Food Drug Anal 10: 178-182.

Craig WJ 1999. Health-promoting properties of common herbs. Am J Clin Nutr 70: 491-499.

Daniel RS, Devi KS, Augusti KT, Sudhakaran NCR 2003. Mechanism of action of antiatherogenic and related effects of Ficus bengalensis Linn. flavanoids in experimental animals. Indian J Exp Biol 4: 296-303.

Folch J, Lees M, Stanley SGH 1957. A simple method for the isolation and purification of total lipids from animal tissues. J Biol Chem 226: 497-509.

Friedewald WT, Levy RI, Fredrickson DS 1972. Estimation of the concentration of low-density lipoprotein cholesterol in plasma, without use of the preparative ultracentrifuge. Clin Chem 18: 499-502.

Goad LJ, Akihisa T 1997. Quantification of sterol by colorimetric assay. Analysis of sterols. 1. ed. London: Chapman and Hall, p. 423-425.
Han LK, Zheng YN, Xu BJ, Okuda H, KimuraY 2002. Saponins from Platycodi radix ameliorate high diet-induced obesity in mice. J Nutr 132: 2241-2245.

Hitz J, Steinmetz J, Siest G 1983. Plasma lecithin: cholesterol acyl transferase reference values and effects of xenobiotics. Clin Chim Acta 133: 85-96.

Ikeda I, Sugano M 1998. Inhibition of cholesterol absorption by plant sterols for mass intervention. Curr Opin Lipidol 9: 527-531.

Itaya K, Ui M 1965. Colourimetric determination of free fatty acids in biological fluids. J Lipid Res 6: 16-20.

Jadeja R, Thounaojam M, Ansarullah, Ramachandran AV, Devkar R 2009. Phytochemical constituents and free radical scavenging activity of Clerodendron glandulosum.coleb methanolic extract. J Compl Integr Med 6: 19.

Kala C P 2005. Ethnomedicinal botany of the Apatani in the Eastern Himalayan region of India. J Ethnobiol Ethnomed 1: 11 .

Khanna K, Ramesh C, Kapoor NK 1996. Terminalia arjuna: an ayurvedic cardiotonic, regulates lipid metabolism in hyperlipaemic rats. Phytother Res 10: 663-665.

Klein RL, Rudel LL 1983. Cholesterol absorption and transport in thoracic duct lymph lipoproteins of nonhuman primates. Effect of dietary cholesterol level. J Lipid Res 24: 343356.

Kothari HV, Miller BF, Kritchevsky D 1973. Aortic cholesterol esterase: characteristics of normal rat and rabbit enzyme. Biochim Biophys Acta 296: 446-454.

Legraud A, Guillansseav R, Land J 1979. Method colorimetric simple determination del'actirit, de la lecithin cholesterol acyltransferase (LCAT) plasma fique. Interest on diabetologic. In: Siest G, Glateau MM (Eds.) Biologic Prospective. Paris: Masson, p. 368-371.

Lehmann JM, Kliewer SA, Moore LB, Smith-Oliver TA, Oliver BB, Su JL, Sundseth SS, Winegar, DA, Blanchard DE, Spencer TA, Willson TM 1997. Activation of the nuclear receptor LXR by oxysterols defines a new hormone response pathway. $J$ Biol Chem 272: 3137-3140. 
Lowry OH, Rosebrough NJ, Farr AL, Randall RJ 1951. Protein measurement with the folin phenol reagent. $J$ Biol Chem 193: 265-275.

Ma PT, Gil G, Südhof TC, Bilheimer DW, Goldstein JL, Brown MS 1986. Mevinolin, an inhibitor of cholesterol synthesis, induces mRNA for low density lipoprotein receptor in livers of hamsters and rabbits. P Natl Acad Sci USA 83: 8370-8374.

Mays PA, Felts JM 1968. The functional status of lipoprotein lipase in rat liver. Biochem J 108: 483-487.

Mosback EH, Klenisky HJ, HalP, Kendall EE 1954. Determination of deoxycholic acid and cholic acid in bile. Arch Biochem Biophys 51: 402-409.

Purkayastha J, Nath S C, Islam M 2005. Ethnobotany of medicinal plants from Dibru-Saikhowa Biosphere Reserve of Northeast India. Fitoterapia 76: 121-127.

Qi K, Seo T, Jiang Z, Carpentier YA, Deckelbaum RJ 2006. Triglycerides in fish oil affect the blood clearance of lipid emulsions containing long-and medium-chain triglycerides in mice. $J$ Nutr 136: 2766-2772.

Radhakrishnan K 2008.The Hindu: Kerela News. Cardaic ailment: figures and frightening. India's National Newspaper, July 09 India.

Rao AV, Ramakrishnan S 1975. Indirect assessment of hydroxymethylglutaryl-Co A reductase (NADPH) activity in liver tissue. Clin Chem 21: 1523-1525.

Rathi AB, Nath N, Chari SN 1984. Action of bioflavonoids on lipid peroxidation \& glutathione redox system in hypercholesterolemic rats. Indian J Med Res 79: 508513.

Reiner Z, Tedeschi-Reiner E 2006. Atherosclerosis-a paradox of Eastern European countries. Atherosclerosis 7/3(Suppl.): 461.

Richard NF 2008. Statin Drugs. http://heartdisease.about.com/ b/2008/01/14/enhance-at-best-no-benefit-from-vytorinor-zetia.htm.

Rudel LL, Shelness GS.2000. Cholesterol esters and atherosclerosis-a game of ACAT and mouse. Nat Med 6: 1313-1314.

Sattler W, Levak-evak S, Radner H, Kostner GM, Zechner R 1996. Muscle-specific overexpression of lipoprotein lipase in transgenic mice results in increased a-tocopherol levels in skeletal muscle. Biochem J 318: 15-19.

Song HY, Rho MC, Lee SW, Kwon OE, Chang YD, Lee HS, Kim YK 2002. Isolation of Acyl-CoA: cholesterol acyltransferase inhibitor from Persicaria vulgaris. Planta med 68: 845-847.

Sudhir K 2002. The Medicinal Plants of North-East India. Jodhpur: INDIA.

Thounaojam, M., Jadeja, R., Ansarullah., Devkar, R and Ramachandran A.V.(2009) Dysregulation of lipid and cholesterol metabolism in high fat diet fed hyperlipidemic rats: Protective effect of Sida rhomboidea. Roxb leaf extract. J Health Sci 55: 413-420.

Valiathian MS 1998. Healing plants. Curr Sci India 75: 11221126.
Wilson PW, Abbott RD, Castelli WP 1988. High density lipoprotein cholesterol and mortality. The Framingham Heart Study. Atherosclerosis 8: 737-741.

Wilson PWF 1990. High density lipoprotein, low density lipoprotein and coronary heart disease. Am J Cardiol 66: 7-10.

Xi M, Hai C, Tang H, Chen M, Fang K, Liang X 2007. Antioxidant and antiglycation properties of total saponins extracted from traditional Chinese medicine used to treat diabetes mellitus. Phytother Res 22: 228-237.

Yen G, Hsieh C 1998. Antioxidant activity of extracts from Du-zhong (Eucommia ulmoides) toward various lipid peroxidation models in vitro. J Agr Food Chem 46: 39523957.

Yokozawa T, Ishida A, Cho EJ, Nakagawa T 2003. The effects of Coptidis rhizoma extract on a hypercholesterolemic animal model. Phytomedicine 10: 17-22.

Zhang Z, Li DS, Blanchard DE, Lear SR, Erickson SK, Spencer TA 2001. Key regulatory oxysterols in liver: analysis as $\Delta^{4}$-3-ketone derivatives by HPLC and response to physiological perturbations. J Lipid Res 42: 649-658. 